\title{
Spread of Citrus Tristeza Virus in Citrus Orchards in Central California
}

\author{
Raymond K. Yokomi, ${ }^{1, \dagger}$ Mark S. Sisterson, ${ }^{1, \dagger}$ and Subhas Hajeri ${ }^{2}$ \\ ${ }^{1}$ United States Department of Agriculture-Agricultural Research Service, San Joaquin Valley Agricultural Sciences Center, 9611 \\ South Riverbend Avenue, Parlier, CA 93648-9757, U.S.A. \\ ${ }^{2}$ Citrus Pest Detection Program, Central California Tristeza Eradication Agency, 22847 Road 140, Tulare, CA 93274-9367, \\ U.S.A.
}

\begin{abstract}
In California, citrus tristeza virus (CTV) is regulated by a State Interior Quarantine. In CTV abatement districts in central California, trees with CTV that react to MCA13 (MCA13-positive [MCA13+]), a straindiscriminating monoclonal antibody, are rogued to prevent virus spread. The Tulare County Pest Control District, however, does not participate in this abatement program except for a $1.6-\mathrm{km}^{2}$ zone around the Lindcove Research and Extension Center, Exeter, CA. To quantify CTV spread under these two disparate management programs, CTV surveys were conducted in abatement plots with mandatory aphid control and nonabatement plots. Abatement plot surveys used hierarchical sampling of $25 \%$ of trees with samples pooled from four adjacent trees. Detection

in nonabatement plots, incidence of CTV increased by an average of $4.6 \%$ between 2015 and 2018. Increase in MCA13-negative (MCA-) isolates was 11 times greater than that of MCA13+ isolates, with the number of MCA13+ trees increasing by 19 trees between 2015 and 2018. MCA13- isolates were more randomly distributed, suggesting primary spread, whereas MCA13+ CTV isolates were more aggregated, suggesting some secondary spread. These results suggest that spread of MCA13+ isolates was limited by a combination of tree removal and aphid vector suppression. MCA13+ samples were VT isolates with some mixtures with T30 isolates. Despite the presence of VT isolates, all CTVinfected trees were asymptomatic.
\end{abstract} of MCA13+ CTV in a sample prompted resampling and testing of individual trees. From 2008 to 2018, incidence of CTV increased by an average of $3.9 \%$, with only two MCA13+ samples detected. In contrast,
Keywords: disease management epidemiology, eradication, fruit, genetic diversity, genotype, tree fruits, viruses and viroids
Citrus tristeza virus (CTV) is the most destructive virus affecting citrus (Bar-Joseph et al. 1989). CTV belongs to genus Closterovirus and comprises a complex of genetically distinct strains (Moreno and Garnsey 2010). It is a foregut-borne virus transmitted in a semipersistent manner by aphids. The virus acquisition can occur within 1 to $24 \mathrm{~h}$ of feeding on an infected plant, there is no latent period, inoculation can occur within 1 to $24 \mathrm{~h}$ after acquisition, and there is no transmission after a molt unless the virus is reacquired (Raccah et al. 1976). In California, Aphis gossypii (Hemiptera: Aphididae) is the principal vector of CTV (Dickson et al. 1956; Roistacher et al. 1984; Yokomi and DeBorde 2005). The host range of A. gossypii is broad and includes citrus (Kono and Papp 1977). Transmission of CTV by A. gossypii is considered less efficient compared with the brown citrus aphid (Toxoptera citricida; Hemiptera: Aphididae), which is not present in California (Yokomi and DeBorde 2005).

Symptom expression of CTV depends on the strains and host cultivar-rootstock combination (Moreno and Garnsey 2010). Quick decline strains induce bud union girdling and rapid tree death when scions are grafted on sour orange rootstocks. The most virulent strains cause pitting in trunks and branches and cheesy bark in the

${ }^{\dagger}$ Corresponding authors: R. Yokomi; ray.yokomi@usda.gov; and M. S. Sisterson; mark.sisterson@usda.gov

Funding: Financial support for this research was provided by the Tulare County Pest Control District Board (58-22000-011-08T) administered through the Citrus Research Board (grant 5300-185).

Mention of trade names or commercial products in this publication is solely for providing specific information and does not imply recommendation or endorsement by the U.S. Department of Agriculture. USDA is an equal opportunity provider and employer.

The author(s) declare no conflict of interest.

Accepted for publication 11 February 2020.

This article is in the public domain and not copyrightable. It may be freely reprinted with customary crediting of the source. The American Phytopathological Society, 2020. inner face of bark regardless of rootstock, leading to poor fruit production and quality (Garnsey et al. 2005). Other CTV isolates are mild and result in symptomless infections, especially when planted on CTV-resistant or -tolerant rootstocks.

CTV is a quarantine pest in California and is regulated by the State Interior Quarantine $\$ 3407$ (CDFA 2011). During the 1960s, the grower-funded Central California Tristeza Eradication Agency (CCTEA), Tulare, CA, rogued CTV-infected trees in five Pest Control Districts (PCDs) in Fresno, Kern, and Tulare Counties under a joint operating agreement (Polek 2010). Initially, CTV detection was based on graft inoculation to Mexican lime indicator plants held in a temperature-controlled greenhouse (Roistacher 1991). Because the test required months to complete, a limited number of samples were tested each year. In 1990, an enzyme-linked immunosorbent assay (ELISA) that used a universal coat protein (CP)-based CTV polyclonal antiserum (PCA) was adopted for CTV diagnosis. The efficiency of the ELISA test greatly increased the diagnostic capacity of the CCTEA and enabled an intensified effort to eradicate CTV in central California in 1995. This resulted in two PCDs leaving the eradication program in 1995-96, citing costs and concern that trees identified for removal were asymptomatic and productive. Therefore, from 1996 to 2007, only three PCDs continued annual surveys and removal of all CTV-positive trees based on ELISA screening. A resultant increase in CTV incidence in the buffer area between abatement and nonabatement PCDs made eradication in abatement districts unfeasible (Barnier et al. 2010). Consequently, the CCTEA adopted a new ELISA protocol in 2009 by changing the antiserum to MCA13, a monoclonal antibody that reacts selectively with many virulent isolates of CTV (Permar et al. 1990). MCA13 reactivity (MCA13-positive [MCA13+]) has been associated with a structural epitope on the $\mathrm{CP}$ which is largely conserved among severe isolates of CTV. Specifically, this epitope has a phenylalanine mutation at position 124 of the $\mathrm{CP}$ gene, whereas MCA13-negative (MCA13-) isolates have a tyrosine at this position (Pappu et al. 1993). Under the current plan, only trees infected with MCA13+ CTV are rogued in participating districts (Barnier et al. 2010).

Although the Tulare County PCD (TCPCD) does not participate in the CTV abatement program, there is a special abatement district to 
protect citrus from CTV spread in a $1.6 \mathrm{~km}^{2}$ zone around the Lindcove Research and Extension Center (LREC), Exeter, CA, that houses the Citrus Clonal Protection Program (CCPP) and $>10,000$ field citrus trees. To determine the effects of roguing MCA13+ trees and aphid suppression program on CTV spread, surveys were conducted in citrus plots located in abatement and nonabatement zones using ELISA.

\section{Materials and Methods}

Plot locations and orchard management. During the study, seven orchards were surveyed over multiple years to evaluate incidence and spread of CTV in the TCPCD. Four orchards were in the LREC abatement zone and three orchards were in an adjacent nonabatement area. In the special abatement district, surveys for and removals of MCA13+ trees are conducted annually to suppress the spread of severe CTV isolates. In addition, growers are required to apply a foliar treatment of Assail (acetamiprid) in spring and imidacloprid in fall for aphid vector control (Barnier et al. 2010). To ensure full grower participation, guidance and funding for this program are provided by the TCPCD (Barnier et al. 2010). Citrus in all of the plots were on Carrizo rootstock and were of fruit-bearing age. Citrus cultivars included Valencia (plot 23 and plot 24), Washington Navels (plot 26), and Minneola tangelo (plot 30).

Nonabatement plots were near Exeter, CA and orchard management was in accordance with the California Navel and Valencia Exports to Korea program (NAVEK). The NAVEK program requires that growers apply fungicides to control Septoria spot, herbicides to control weeds, and two insecticide treatments to control Fuller rose beetle, Naupactus godmani (Coleoptera: Curculionidae). Plot 13 is 1.6 ha of Washington Navel; plot 21 is 7.7 ha of Washington Navel; and plot 22 is 10 ha with mixed planting of Minneola tangelo (51\%), Frost Navel (40\%), and Valencia (9\%).

Pesticide application records were graciously provided by the growers and confirmed that all mandated treatments were applied on schedule in both the abatement and nonabatement plots.

Citrus sampling. In abatements plots, a hierarchical subsampling (HS) (Hughes and Gottwald 1999) plan was followed, in which $25 \%$ of the trees in a plot were sampled. With this protocol, trees in a plot were subgrouped into four-tree units. Every fourth unit is sampled by collecting 3 fully expanded young leaves from each of the four trees and combining the 12 leaves into one sample. Diagnostic testing conducted between 2008 and 2011 as well as in 2018 tested each sample for reactivity to PCA and MCA13. However, between 2011 and 2017 , trees in the abatement plots were only tested with MCA13. Composite samples that tested positive by MCA13 were retested as two tree samples or individually to identify trees infected with MCA13+ CTV isolates.

In nonabatement plots, all trees were individually sampled and tested in spring 2015 and 2018. Three fully expanded young leaves from new shoots on each quadrant (north, south, east, and west) were collected, labeled, and returned to the laboratory where leaf petioles were excised, and the 12 petioles collected from each tree were pooled for serology by ELISA. Each tree was tested for reactivity to CTV PCA and MCA13.

Serology. Leaf petioles were processed as prescribed in the CCTEA protocols (Maheshwari et al. 2017; Polek 2010; Yokomi et al. 2018). Specifically, approximately $0.5 \mathrm{~g}$ of petiole was placed in a stainlesssteel canister with a large stainless-steel ball and filled with $5 \mathrm{ml} \mathrm{(1:20}$ [wt/vol]) of PEP (0.01 M sodium phosphate, $\mathrm{pH} 7.4 ; 0.14 \mathrm{M} \mathrm{NaCl}$; $2.68 \mathrm{mM} \mathrm{KCl}$; and $0.04 \%$ Tween 20 ) containing $2 \%$ polyvinylpyrrolidone 10 and ground vigorously for $10 \mathrm{~s}$ in a Kleco Tissue Homogenizer (Garcia Manufacturing, Visalia, CA, U.S.A.). Serology was performed using double-antibody sandwich indirect ELISA in 96-well polystyrene plates. Chicken and rabbit PCAs were made to whole virions of FL rCTV T36 produced in Nicotiana benthamiana by Cocalico Biologicals, Inc. (Reamstown, PA, U.S.A.) (Maheshwari et al. 2017). The chicken PCA was used for coating and the rabbit PCA was used as the second antiserum for broad-spectrum CTV ELISA. A goat antirabbit phosphate conjugate was used to detect a positive ELISA by addition of an alkaline phosphate substrate and reaction read by an ELISA plate reader (Molecular Devices, San Jose, CA, U.S.A.).
Tissue extracts from the same sample were also tested by ELISA using MCA13 as the detecting antibody on rabbit PCA-coated plates. For trees tested with the PCA and the MCA13 antibodies, CTV infections were placed into one of three groups: MCA13+; MCA13- but PCA positive; and CTV negative.

Immunocapture real-time reverse-transcription PCR. Trees identified as MCA13+ in nonabatement plots during 2015 were subjected to additional analysis via immunocapture real-time reversetranscription PCR (IC-RT-qPCR). Specifically, each MCA13+ tree was tested with CTV strain-specific primers and probes for VT, T36NS, T36 (Yokomi et al. 2010), T30 (Ruiz-Ruiz et al. 2009), and S1 (Yokomi et al. 2018) isolates, using methods described by Yokomi (2019). Total nucleic acids extracted from healthy control plants and plants infected with T30, RB, S1, T36, and VT isolates were used as controls in the RT-qPCR tests. Cycle threshold $(\mathrm{Ct})$ values $<32$ were considered CTV positive. MCA13- trees from nonabatement district plots were not subjected to additional analyses because previous testing conducted in conjunction with other CTV surveys in Tulare and Kern Counties, CA, indicated that MCA13- trees typically were infected by a T30 strain of CTV (Selvaraj et al. 2019).

CTV symptomology. Visual ratings were conducted in spring 2019 on a selected group of 50 trees that were MCA13+ and VT genotype-positive along with five trees that were PCA-positive but MCA-negative and five trees that were PCA-negative. Trees were rated for chlorosis, stunting, and twig dieback. To look for stem pits, bark was peeled from 1-year-old branches and stems (Garnsey et al. 2005; Roistacher 1991).

Statistical analysis of temporal spread in abatement orchards. Because abatement orchards were sampled using an HS approach, analyses in abatement orchards were limited to evaluating temporal trends. To determine whether the change in CTV incidence in abatement orchards between 2008 and 2018 was significant, 95\% confidence intervals (CIs) for HS estimates of incidence were constructed. If CIs from 2008 and 2018 overlapped, estimates of incidence during the two time periods were not statistically different.

Statistical analysis of temporal and spatial spread in nonabatement orchards. Surveys in nonabatement orchards were conducted in 2015 and 2018. Incidence and spatial distribution of CTV-affected trees observed in 2015 reflected management actions between planting and sampling, including termination of CTV surveys in 1996 (Barnier et al. 2010). In contrast, virus infections that occurred between 2015 and 2018 reflected management actions between surveys. Analyses were conducted to determine whether patterns of spread of MCA13+ and MCA13- CTV isolates prior to 2015 differed from patterns observed between 2015 and 2018. The first analysis compared incidence of MCA13+ and MCA13- trees in 2015 across the three plots using a paired $t$ test. Subsequently, the annual rate of spread of MCA13 between 2015 and 2018 was estimated for each plot by dividing the difference in incidence between 2018 and 2015 by 3 years. Annual rates of pathogen spread between 2015 and 2018 were compared using a paired $t$ test.

To determine whether spatial distribution of CTV-infected trees in study plots during 2015 were randomly distributed or aggregated because of primary or secondary spread, respectively, a Monte Carlo simulation approach was used (Manly 1997; Sisterson et al. 2012). To conduct Monte Carlo simulations, a program was written in $\mathrm{C}++$ (Microsoft Visual C++; Redmond, WA, U.S.A.). First, the program analyzed the observed data set from 2015. For the analysis, mean distance of each CTV-affected tree to the $i$ th nearest infected tree was determined. For example, mean distance of each infected tree to the nearest $(i=1) \mathrm{CTV}$-infected tree was determined. Subsequently, mean distance to the second nearest infected tree was determined $(i=2)$. This process was continued until the mean distance to the 10th nearest $(i=10) \mathrm{CTV}$-infected tree was determined. After estimating observed values, 1,000 Monte Carlo simulations were conducted. For each Monte Carlo simulation, the same number of infections were randomly distributed in an orchard with the same number of rows and trees per row as the observed data set. The mean distance of each CTV-infected tree to the $i$ th nearest CTV-infected tree was determined for the simulated data set. The results of the 
1,000 Monte Carlo simulations were used to construct 95\% CIs that represented the range of expected distances to the $i$ th nearest infected tree under the assumption that infections were randomly distributed. If the observed mean distance to the ith infected tree falls within the range of the $95 \% \mathrm{CI}$, the spatial distribution of CTVinfected trees may be considered random. However, if the observed mean distance to the $i$ th infected tree falls below the range of the 95\% CI, the spatial distribution of CTV-infected trees may be considered aggregated.

To determine whether infections that occurred after the first survey in 2015 were random with respect to location of infections present during the first survey, a similar Monte Carlo approach was used for the 2018 data. As with the 2015 data, the mean distance to the $i$ th nearest infected tree was determined. However, mean distances were only estimated for infections that arose after 2015. Monte Carlo simulations took place in two steps. First, for each Monte Carlo simulation, the known distribution of infected trees in 2015 was used. Once known infections were assigned to the same location as in the observed data set, the same number of infections that arose between 2015 and 2018 were randomly distributed throughout the orchard, with distances to the $i$ th infected tree determined only for trees that became infected after 2015. Because the Monte Carlo simulations used the known distribution of infected trees in 2015 and only distances for infections that arose after 2015 were estimated, the analysis quantifies the spatial distribution of new infections relative to infections present in 2015 .

\section{Results}

Spread of CTV in abatement orchards. In abatement district orchards, only two Minneola trees were MCA13+ during annual surveys conducted between 2008 and 2018. Both trees were observed in 2010 and promptly removed. Trees that tested positive by PCA were not removed (Table 1). Only a small increase in estimated overall annual incidence of CTV was observed from 2008 to
2018, increasing from 2.8 to $5.9 \%$ (Table 1). The $95 \%$ CIs for annual estimated CTV incidence overlapped in plots 23 and 24 but not in plot 26 (Navel), where the estimated CTV incidence rose from 4.8 to $15.2 \%$ between 2011 and 2018 (Navel), and in plot 30 (Minneola), where estimated incidence rose from 1.9 to $6.9 \%$ during this same period.

Spread of CTV in nonabatement orchards. In 2015, the percentage of MCA13+ and MCA13- trees did not differ across orchards $(t=0.88, \mathrm{df}=2, P=0.47)$ (Table 2). At two sites (plots 13 and 22), incidence of MCA13- CTV isolates was greater than incidence of MCA13+ isolates. However, in plot 21, incidence of MCA13+ isolates was greater than incidence of MCA13- isolates in 2015. Between 2015 and 2018, the mean rate of spread of MCA13- CTV isolates was 11 times greater than the mean rate of spread of MCA13+ isolates (mean annual rate of spread of MCA13+ isolates $=0.12$; mean annual rate of spread of MCA13CTV isolates $=1.39 ; t=3.4, \mathrm{df}=2, P=0.08$ ).

Spatial distributions of MCA13- trees in 2015 were marginally aggregated in plots 13 and 22 (Figs. $1 \mathrm{~A}$ and $\mathrm{E}$ and $2 \mathrm{~A}$ and $\mathrm{E}$ ) and randomly distributed in plot 21 (Figs. 1C and 2C). In contrast, spatial distributions of MCA13+ trees in 2015 were significantly aggregated in plot 21 and plot 22 (Figs. $1 \mathrm{C}$ and $\mathrm{E}$ and $2 \mathrm{D}$ and F). Spatial distribution of MCA13+ CTV in plot 13 during 2015 conformed to a random model; however, only three MCA13+ CTV-infected trees were found in 2015 (Fig. 1A).

For MCA13- CTV isolates, the distribution of infections that arose after 2015 conformed to a random model for all three plots (Fig. 3A, C, and E). In contrast, the distribution of MCA13+ isolates that arose after 2015 was aggregated in plot 21 and plot 22 (Fig. 3D and F). Although observed values for MCA13+ isolates were within the $95 \%$ CI for plot 13 (Fig. 3B), only one additional tree became infected with an MCA13+ strain between 2015 and 2018 (Fig. 1A and $\mathrm{B})$.

CTV isolates and symptomology. In 2015, in nonabatement plots, 558 trees were positive for CTV (15.9\%), with 236

Table 1. Incidence of citrus tristeza virus (CTV) in citrus orchards in an abatement area within $1.6 \mathrm{~km}$ of the Lindcove Research and Education Center, Exeter, CA where annual aphicide sprays, CTV surveys, and roguing of MCA13-positive (MCA13+) trees are implemented by a grower-supported program

\begin{tabular}{|c|c|c|c|c|c|c|c|c|c|}
\hline \multirow[b]{2}{*}{ Plot } & \multirow[b]{2}{*}{ Cultivar } & \multirow[b]{2}{*}{$N^{\mathbf{a}}$} & \multirow[b]{2}{*}{ Area $^{\mathbf{b}}$} & \multicolumn{6}{|c|}{ Estimated CTV percent incidence (lower and upper bounds of $95 \%$ CI) } \\
\hline & & & & 2008 & 2009 & 2010 & 2011 & $2012-17^{d}$ & 2018 \\
\hline 23 & Valencia & 1,804 & 7.8 & $0.6(-0.2,1.4)$ & $1.3(0.1,2.5)$ & $1.6(0.4,2.8)$ & $2.7(1.1,4.3)$ & N/A & $2.9(1.3,4.5)$ \\
\hline 24 & Valencia & 1,673 & 7.4 & $3.6(1.8,5.4)$ & $3.1(1.3,4.9)$ & $4.3(2.3,6.3)$ & $2.5(0.9,4.1)$ & N/A & $4.0(2.0,6.0)$ \\
\hline 26 & Navel & 903 & 3.8 & $6.2(2.9,9.5)$ & $5.3(2.2,8.4)$ & $9.2(5.1,13.3)$ & $4.8(1.9,7.7)$ & N/A & $15.2(9.9,20.5)$ \\
\hline 30 & Minneola & 1,543 & 3.8 & $2.9(1.1,4.7)$ & $2.7(1.3,4.1)$ & $3.0(1.4,4.6)$ & $1.9(0.5,3.3)$ & N/A & $6.9(4.2,9.6)$ \\
\hline Total & $\ldots$ & 5,923 & 22.8 & 2.8 & 2.8 & 3.8 & 2.8 & N/A & 5.9 \\
\hline
\end{tabular}

a Number of trees.

b Plot area in hectares.

${ }^{c}$ CTV incidence estimated by the $25 \%$ hierarchical survey method (Hughes and Gottwald 1999). Units are the estimated percentage of trees infected using a universal polyclonal antibody (PCA) that detects all CTV isolates. Lower and upper bounds of the $95 \%$ confidence interval (CI) were determined using hierarchical subsampling (HS) estimate $\pm 1.96 \times$ standard error (SE). SE was calculated as the SQRT of Variance/SQRT of HS samples taken.

${ }^{\mathrm{d}}$ N/A = no data were collected using PCA universal CTV detection between 2012 and 2017. However, all samples throughout the survey were tested by MCA13 (Pappu et al. 1993; Permar et al. 1990). Only two Minneola trees were MCA13+ in 2010 and were removed.

Table 2. Number of citrus tristeza virus-infected (CTV) trees in three nonabatement orchards near Exeter, CA, comparing those that were MCA13-positive (MCA13+) and MCA13-negative (MCA13-) versus total CTV-infected trees in 2015 and 2018

\begin{tabular}{|c|c|c|c|c|c|c|c|c|}
\hline \multirow[b]{3}{*}{ Plot } & \multirow[b]{3}{*}{$N^{\mathbf{b}}$} & \multirow[b]{3}{*}{ Area $^{c}$} & \multicolumn{6}{|c|}{ Number of trees (percentage of total trees) } \\
\hline & & & \multicolumn{3}{|c|}{2015} & \multicolumn{3}{|c|}{2018} \\
\hline & & & MCA13+ & MCA13- & CTV & MCA13+ & MCA13- & CTV \\
\hline 13 & 384 & 1.6 & $3(0.8)$ & $36(9.4)$ & $39(10.2)$ & $4(1.0)$ & $58(15.1)$ & $62(16.1)$ \\
\hline 21 & 1,134 & 7.7 & $72(6.3)$ & $39(3.4)$ & $111(9.8)$ & 78 (6.7) & $61(5.4)$ & $139(12.3)$ \\
\hline 22 & 2,187 & 10.0 & $161(7.4)$ & $247(11.3)$ & $408(18.7)$ & $173(7.9)$ & $353(16.1)$ & $526(24.1)$ \\
\hline Overall & 3,705 & 19.3 & $236(6.4)$ & $322(8.7)$ & $558(15.9)$ & $255(6.9)$ & $472(12.7)$ & $727(19.6)$ \\
\hline
\end{tabular}

a No roguing of CTV-infected trees occurred in these fields or surrounding area.

b Number of total trees.

c Plot area in hectares. 
MCA13+ trees (6.4\%) (Table 2). The proportion of CTV MCA13+ was 236 of $558(42.3 \%)$. In all, 221 MCA13+ samples were subjected to IC-RT-qPCR with strain-specific primers and probes; 200 were VT $(90.5 \%)$ and 21 were a mixture of VT and T30 isolates $(9.5 \%)$ (Table 3). Previous testing by Selvaraj et al. (2019) suggests that the 322 trees, which reacted only to the universal PCA antibody (i.e., MCA13-), were likely T30 genotypes.

Despite infection with MCA13+ CTV isolates, all trees in the plots were asymptomatic, and no stem pitting was noticed in any of the 50 selected VT-positive trees sampled in spring 2019. In addition, no loss of productivity was noted by the grower.

\section{Discussion}

CTV is spread by graft propagation and by aphid vectors (Moreno et al. 2008). Therefore, certified virus-free budwood is used to propagate citrus trees in California to prevent inadvertent CTV spread by humans (Vidalakis et al. 2010). Moreover, because CTV-infected trees serve as virus reservoirs for aphids to acquire and spread
A

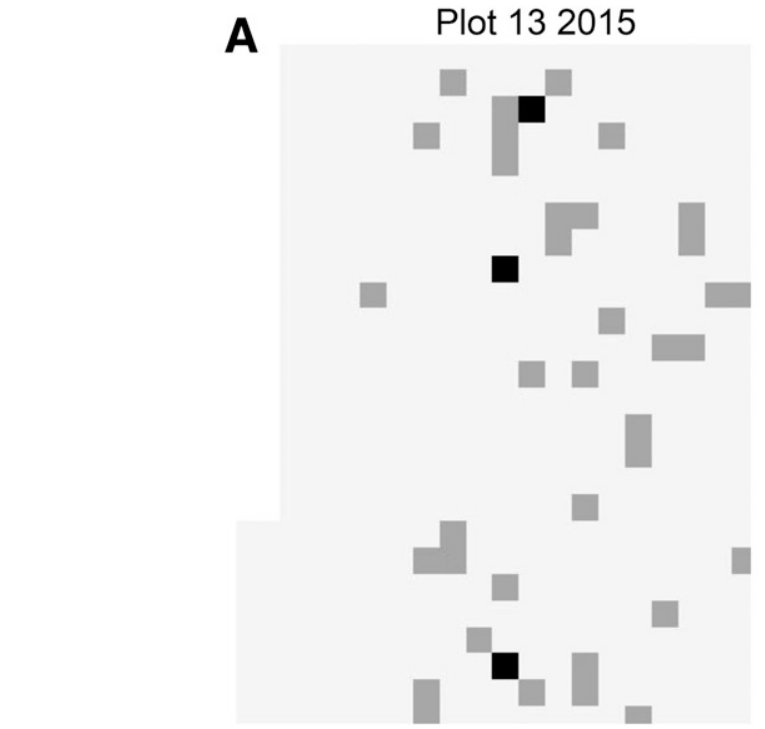

B

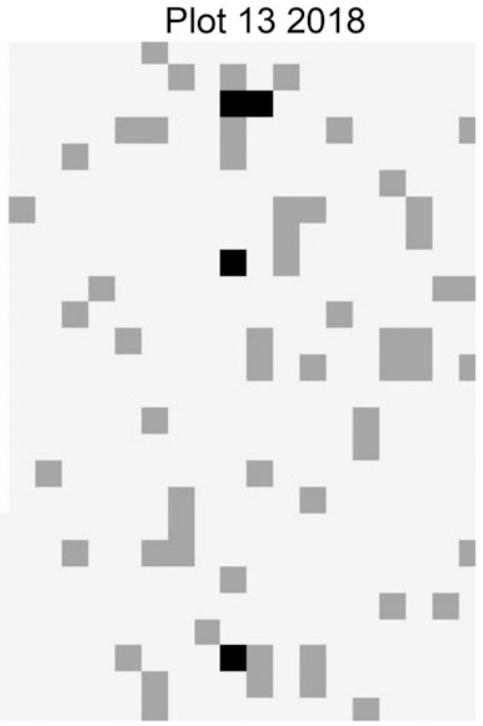

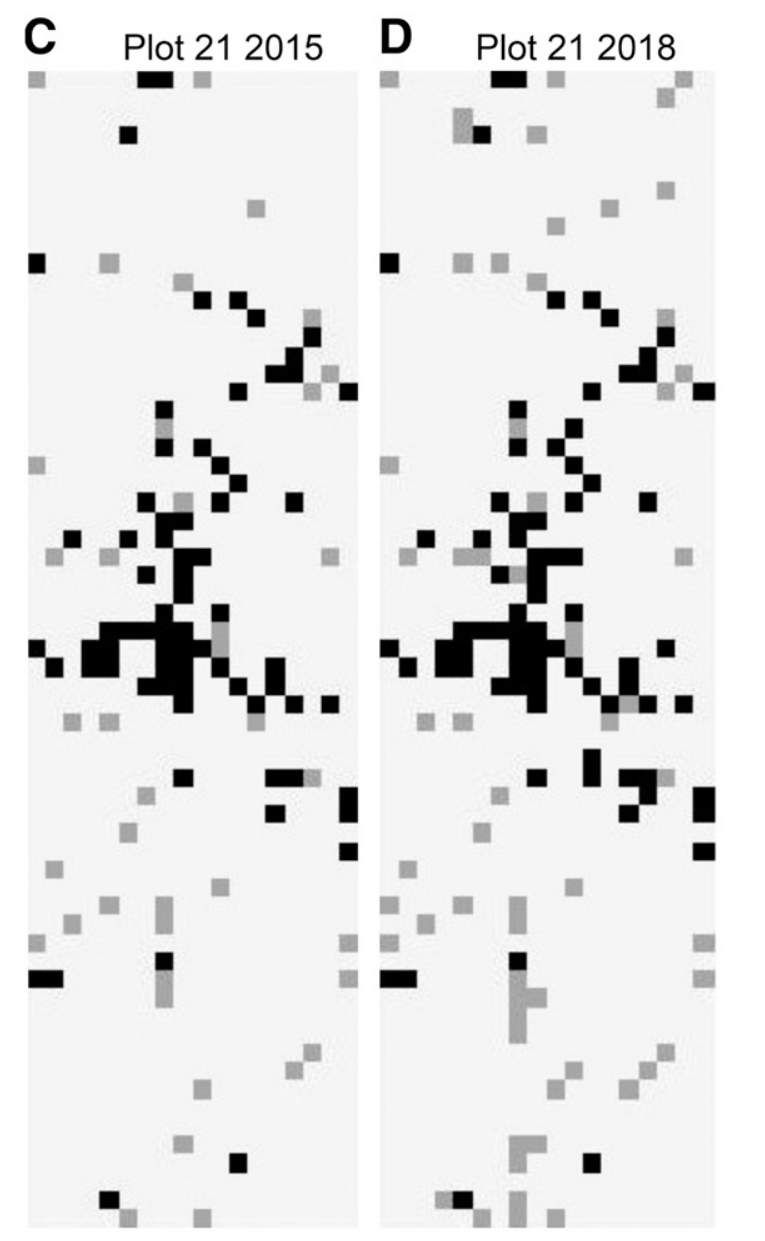

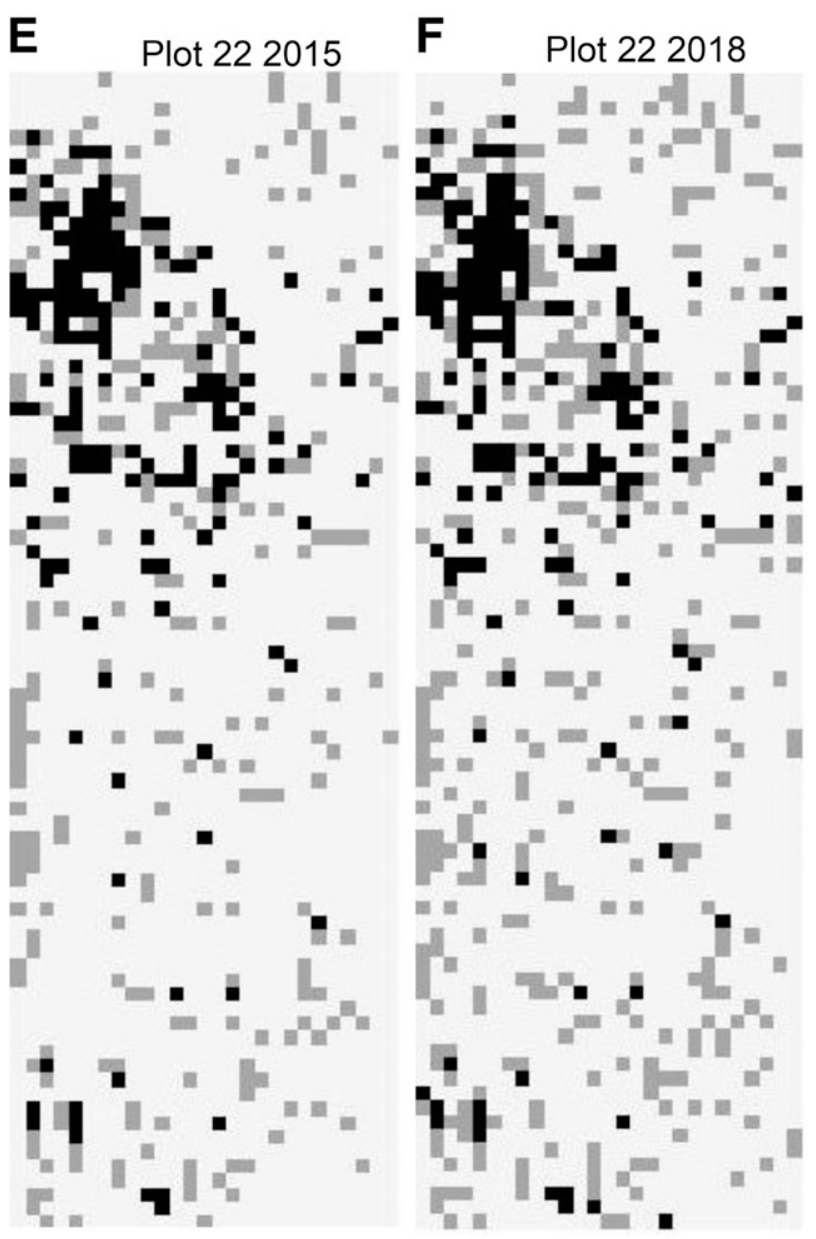

Fig. 1. Spatial distribution of MCA13-negative (MCA13-) (dark gray) and MCA13-positive (MCA13+) (black) citrus tristeza virus (CTV)-infected trees in abatement plots. CTVinfected trees in plot 13 in A, 2015 and B, 2018; plot 21 in C, 2015 and D, 2018; and plot 22 in E, 2015 and F, 2018. 
CTV, roguing programs have been established in several PCDs in central California to suppress the spread of severe CTV isolates (Barnier et al. 2010).

Within an orchard, pathogen spread may occur via two mechanisms: primary spread and secondary spread. Primary spread occurs due to movement of inoculative aphid vectors into an orchard, whereas secondary spread occurs due to acquisition of CTV by a vector within the orchard and movement to another tree within the orchard. Anticipated patterns of virus spread differ for primary and secondary spread. Spatial patterns of infected trees associated with primary spread are likely to be random. In contrast, secondary spread is likely to be represented by the development of aggregations of diseased trees or foci.

This study reports results of CTV spread in an abatement district that surveys orchards and mandates removal of trees infected with MCA13+ CTV isolates and a nonabatement district that does not remove $\mathrm{CTV}$-infected trees.

The abatement orchards were located within a $1.2-\mathrm{km}$ radius of the LREC and were surveyed annually, with MCA13+ trees removed. In addition, growers were mandated to apply insecticides to suppress vector populations in spring and fall (Barnier et al. 2010). Over a 10-year period, only two MCA13+ trees were detected and removed. Thus, MCA13+ isolates were almost nonexistent. In addition, increase of all CTV isolates was limited and was significant in only two of the four plots monitored from 2008 to 2018 (Table 1). Because trees infected with only PCA-reactive isolates were not rogued, this limited spread over the 10 -year sampling period may be attributed to the biannual mandatory aphid spray program.

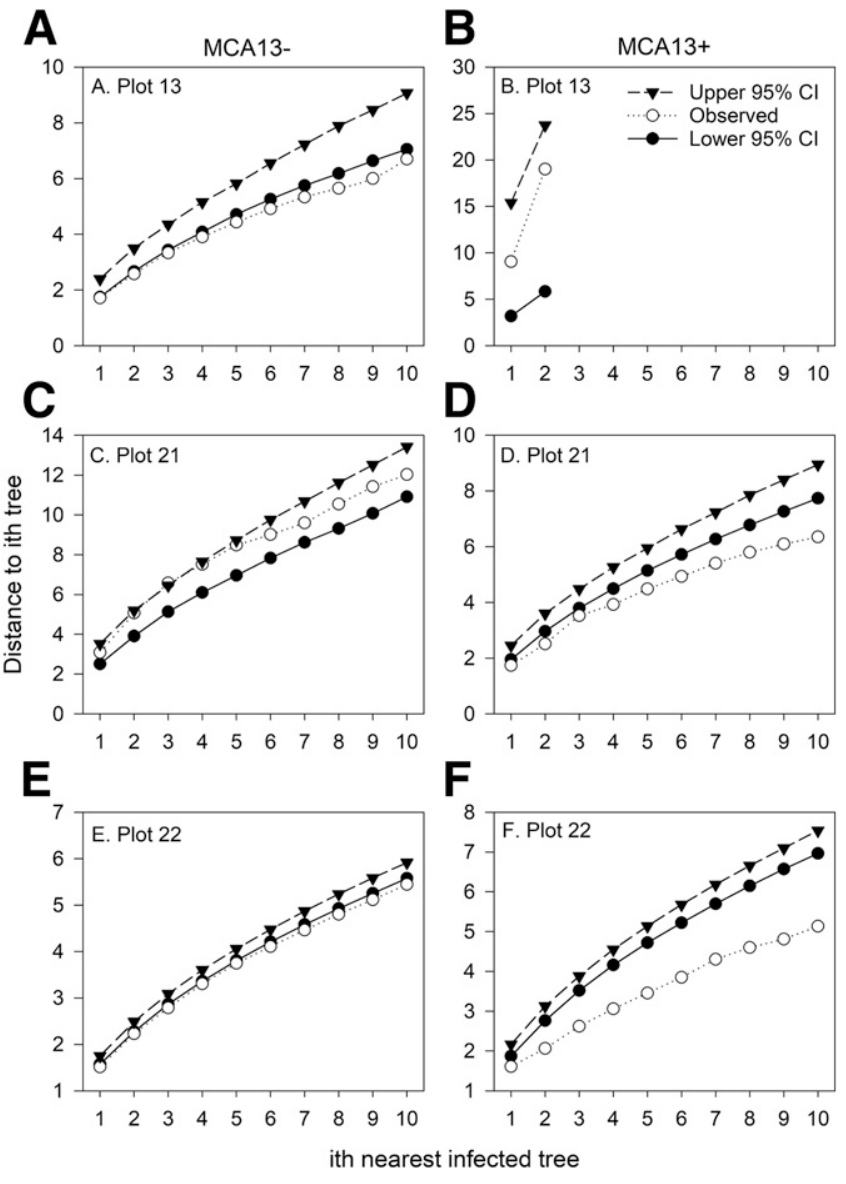

Fig. 2. Result of Monte Carlo simulations based on the spatial distribution of MCA13negative (MCA13-) and MCA13-positive (MCA13+) citrus tristeza virus-infected trees in 2015 for $\mathbf{A}$ and $\mathbf{B}$, plot 13; $\mathbf{C}$ and $\mathbf{D}$, plot 21; and $\mathbf{E}$ and F, plot 22 in abatement plots. Black lines indicate upper and lower bounds of $95 \%$ confidence intervals (Cls) generated assuming that infections were randomly distributed in orchards. If observed values fall within the range of the $95 \% \mathrm{Cl}$, infections may be considered randomly distributed. In contrast, if the observed values fall below the lower range of the $95 \% \mathrm{Cl}$, infections may be considered aggregated.
In nonabatement district plots, MCA13- isolates spread faster than MCA13+ isolates (Table 2). Thus, it is reasonable to hypothesize that rouging of $\mathrm{MCA} 13+$ trees in abatement districts reduced the regional inoculum supply that resulted in lower rates of spread of MCA13+ isolates in the neighboring nonabatement district. This hypothesis is further supported by differences in the spatial distribution of MCA13+ and MCA13- trees in orchards in nonabatement districts. Specifically, MCA13- trees that were infected between 2015 and
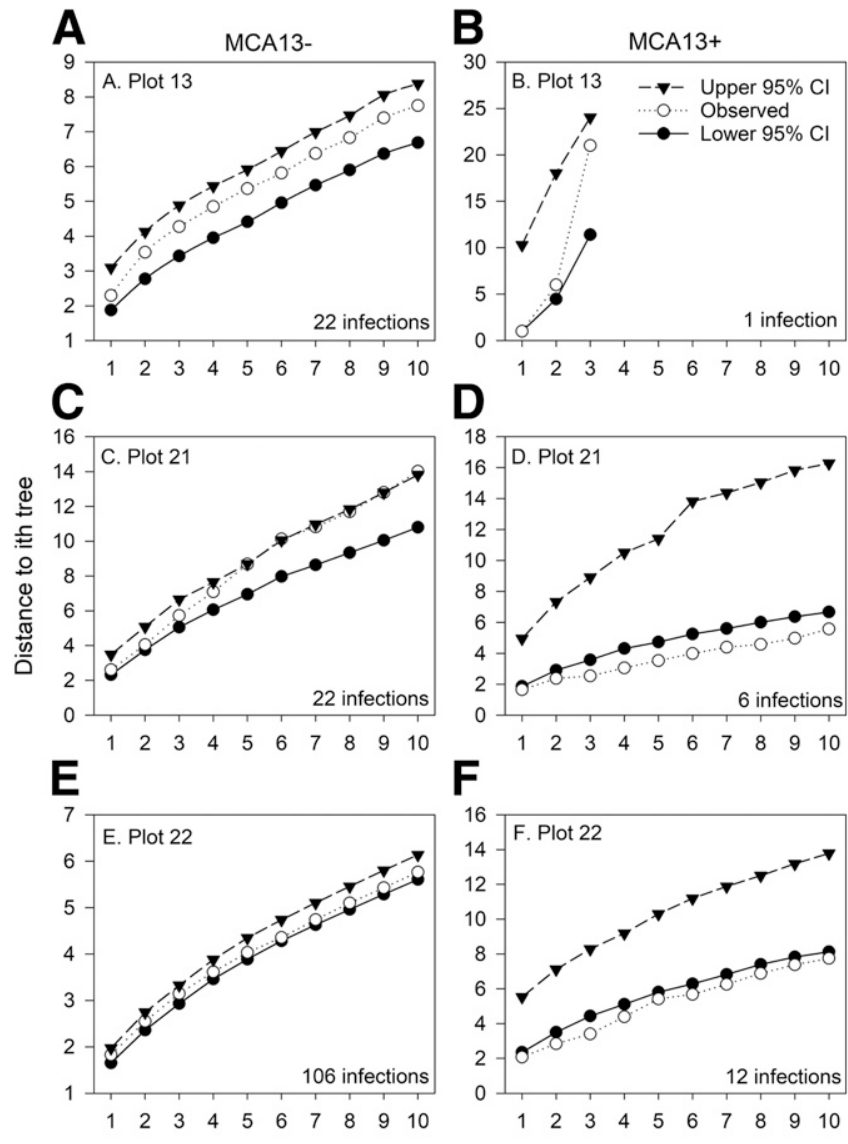

ith nearest infected tree

Fig. 3. Result of Monte Carlo simulations based on the spatial distribution of MCA13negative (MCA13-) and MCA13-positive (MCA13+) citrus tristeza virus-infected trees in 2018 for $\mathbf{A}$ and $\mathbf{B}$, plot 13; C and D, plot 21; and E and F, plot 22 in abatement plots. For Monte Carlo simulations, the known distribution of infected trees in 2015 was used, with the same number of infections that arose after 2015 randomly assigned. The number of infections that arose between 2015 and 2018 is indicated in the bottom right corner of each panel. Black lines indicate upper and lower bounds of $95 \%$ confidence intervals (Cls) generated assuming infections that occurred after 2015 were randomly distributed in orchards. If observed values fall within the range of the $95 \% \mathrm{Cl}$, infections may be considered randomly distributed. In contrast, if the observe values fall below the lower range of the $95 \% \mathrm{Cl}$, infections may be considered aggregated.

Table 3. Typing of MCA13-positive (MCA13+) citrus tristeza virus isolates (CTV) samples obtained in 2015 from nonabatement plots

\begin{tabular}{lcrc}
\hline & & \multicolumn{2}{c}{ CTV isolates } \\
\cline { 3 - 4 } Plot ID & MCA13+a $^{\mathbf{b}}$ & VT & T30+VT \\
\hline 13 & 3 & 2 & 1 \\
21 & 71 & 11 & 0 \\
22 & 147 & 200 & 20 \\
Totals & 221 & 21 \\
\hline
\end{tabular}

${ }^{a}$ Number of isolates. Only 221 of 236 MCA13+ samples collected in 2015 were tested for genotyping CTV isolates.

${ }^{b}$ CTV isolates were differentiated by reverse-transcription quantitative PCR assay using strain-specific primers and TaqMan probes (Yokomi et al. 2010). 
2018 were randomly distributed in orchards, suggesting a primary spread or the movement of inoculative vectors into orchards (Fig. $3 \mathrm{~A}, \mathrm{C}$, and $\mathrm{E}$ ). In contrast, the spatial distribution of MCA13+ trees that were infected between 2015 and 2018 was aggregated, suggesting secondary (tree-to-tree) spread within the orchards (Fig. 3D and F).

Previous studies on CTV epidemiology observed that CTV incidence can increase exponentially if CTV-infected trees are not rogued (Gottwald et al. 1999). Similarly, application of insecticides to suppress vector populations without roguing was also ineffective (Gottwald et al. 2002). A theoretical assessment of factors associated with successful roguing determined that an area-wide roguing approach combined with vector suppression is likely to be most successful (Sisterson and Stenger 2013). In both the abatement and nonabatement plots, insecticides that control aphid populations were routinely applied. Specifically, insecticide sprays mandated in the LREC zone and the NAVEK program in the nonabatement plots were effective in limiting CTV spread. Even in nonabatement plots, where the overall CTV incidence was $15.9 \%$ in 2015 , incidence increased by only $3.7 \%$ in 2018 despite a previous report of high aphid transmission rates of some central California CTV isolates (Yokomi and DeBorde 2005). Aphids were only sporadically observed on young flush, with small colonies forming; however, populations did not persist due to insecticide applications and maturity (hardening) of flush tissue.

Spread of MCA13+ isolates was essentially nonexistent in abatement plots and low in nonabatement districts. Because trees infected by MCA13- isolates are not rogued in either district, it is reasonable to hypothesize that vector suppression methods contributed to their slow spread. Insecticides may be more effective at slowing CTV spread in California with A. gossypii than in regions where T. citricida occurs because this aphid is a more efficient CTV vector and has a host range restricted to the family Rutaceae (Yokomi et al. 1994).

Overall, CTV-infected trees in the nonabatement plots consisted of $35.2 \% \mathrm{VT}$ and VT+ T30 mixtures, with the remaining $64.8 \%$ presumably infected with T30, although not tested in entirety. Visual inspection of selected trees, including those infected with MCA13and MCA13+ with VT genotypes, were asymptomatic and, hence, could not be differentiated from CTV-free trees. No stem-pitting symptoms were observed. In addition, growers did not experience any production or fruit quality losses in these fields even though central California VT isolates have been shown to induce seedling yellows and mild stem pitting in greenhouse bioindexing tests (Yokomi et al. 2017, 2018). Noneconomic impact of CTV was also observed by O'Connell et al. (2010), who concluded that CTV in trees they tested were mild isolates based on vigorous asymptomatic growth and high yield.

Biocharacterization of CTV isolates representative of the abatement and nonabatement districts is currently being conducted in commercial scion cultivars grown on CTV-tolerant rootstocks in a containment screenhouse to simulate field conditions (R. K. Yokomi, unpublished data). Results of disease expression observed in the screenhouse will be relevant for further assessment of the lack of definable CTV impact observed in the present study. However, if virulent stem-pitting strains of CTV are absent, productivity of citrus grown on CTV-tolerant or -resistant rootstocks should continue to be good despite presence of current T30, VT, and other CTV genotype strains in central California as long as current management measures continue.

\section{Acknowledgments}

We thank the owners of the citrus orchards for providing access to sample citrus and providing pesticide records; field and laboratory personnel of the Central California Tristeza Eradication Agency, Tulare, CA for collecting and ELISA testing for CTV; and R. Lee and M. Keremane, United States Department of AgricultureAgricultural Research Service, National Clonal Germplasm Repository For Citrus and Dates, Riverside, CA, U.S.A. for kindly providing MCA13.

\section{Literature Cited}

Bar-Joseph, M., Marcus, R., and Lee, R. F. 1989. The continuous challenge of citrus tristeza virus control. Annu. Rev. Phytopathol. 27:291-316.
Barnier, J., Grafton-Cardwell, B., and Polek, M. 2010. Citrus tristeza virus (CTV): Then and now. Citrograph 1:16-23. http://citrusresearch.org/wp-content/ uploads/Nov-Dec_v2.pdf\#page $=16$

CDFA. 2011. Section 3407 Interior Citrus Tristeza Virus Quarantine. California Department of Food and Agriculture Plant Quarantine Manual 404.1. http:// pi.cdfa.ca.gov/pqm/manual/pdf/404.pdf

Dickson, R. C., Johnson, M. M., Flock, R. A., and Laird, E. F., Jr. 1956. Flying aphid populations in southern California citrus groves and their relation to the transmission of the tristeza virus. Phytopathology 46:204-210.

Garnsey, S. M., Civerolo, E. L., Gumpf, D. J., Paul, C., Hilf, M., Lee, R. F., Brlansky, R. H., Yokomi, R. K., and Hartung, J. S. 2005. Biocharacterization of an international collection of Citrus tristeza virus (CTV) isolates. Pages 75-93 in: Proc. 16th Conf. Int. Org. Citrus Virol. M. E. Hilf, N. Duran-Vila, and M. Rocha-Pena, eds. IOCV, Riverside, CA.

Gottwald, T. R., Abreu-Rodriguez, E., Yokomi, R. K., Stansly, P. A., and Riley, T. K. 2002. Effects of chemical control of aphid vectors and of crossprotection on increase and spread of Citrus tristeza virus. Pages 117-130 in Proc. 15th Conf. Int. Org. Citrus Virol. N. Duran-Vela, R. G. Milne, and J. V. da Graça, eds. IOCV, Riverside, CA.

Gottwald, T. R., Gibson, G. J., Garnsey, S. M., and Irey, M. 1999. Examination of the effect of aphid vector population composition on the spatial dynamics of Citrus tristeza virus spread by stochastic modeling. Phytopathology 89:603-608.

Hughes, G., and Gottwald, T. R. 1999. Survey methods for assessment of Citrus tristeza virus incidence when Toxoptera citricida is the predominant vector. Phytopathology 89:487-494.

Kono, T., and Papp, C. S. 1977. Aphids. Page 13-86 in: Handbook of Agricultural Pests: Aphids, Thrips, Mites, Snails and Slugs. California Department of Food and Agriculture, Sacramento, CA, U.S.A.

Maheshwari, Y., Selvaraj, V., Hajeri, S., Ramadugu, C., Keremane, M. L., and Yokomi, R. K. 2017. On-site detection of Citrus tristeza virus (CTV) by lateral flow immunoassay using polyclonal antisera derived from virions produced by a recombinant CTV. Phytoparasitica 45:333-340.

Manly, B. F. J. 1997. Randomization, Bootstrap, and Monte Carlo Methods in Biology. Chapman and Hall, Washington, DC, U.S.A.

Moreno, P., Ambrós, S., Albiach-Martí, M. R., Guerri, J., and Peña, L. 2008. Citrus tristeza virus: A pathogen that changed the course of the citrus industry. Mol. Plant Pathol. 9:251-268.

Moreno, P., and Garnsey, S. M. 2010. Citrus tristeza diseases-A worldwide perspective. Pages 27-49 in: Citrus Tristeza Virus Complex and Tristeza Diseases. A. V. Karasev and M. E. Hilf, eds. American Phytopathological Society, St. Paul, MN, U.S.A.

O'Connell, N. V., Seymore, A. D., Chaffe-Stengel, P., and Stengel, D. N. 2010 Economic impact of mild strains of Citrus tristeza virus in the San Joaquin Valley. Citrograph 1:24-26. http://citrusresearch.org/wp-content/uploads/NovDec_v2.pdf\#page $=24$

Pappu, H. R., Pappu, S., Manjunath, K. L., Lee, R. F., and Niblett, C. L. 1993 Molecular characterization of a structural epitope that is largely conserved among severe isolates of a plant virus. Proc. Natl. Acad. Sci. U.S.A. 90 3641-3644.

Permar, T. A., Garnsey, S. M., Gumpf, D. J., and Lee, R. F. 1990. A monoclona antibody that discriminates strains of Citrus tristeza virus. Phytopathology 80: 224-228.

Polek, M. 2010. Eradication of tristeza in the Central Valley of California. Pages 219-232 in: Citrus Tristeza Virus Complex and Tristeza Diseases. A. V. Karasev and M. E. Hilf, eds. American Phytopathological Society, St. Paul, MN, U.S.A.

Raccah, B., Loebenstein, G., and Bar-Joseph, M. 1976. Transmission of Citrus tristeza virus by the melon aphid. Phytopathology 66:1102-1104.

Roistacher, C. N. 1991. Techniques for biological detection of specific citrus grafttransmissible diseases: Tristeza. Pages 17-33 in: Graft-Transmissible Disease of Citrus: Handbook for Detection and Diagnosis. C. N. Roistacher, ed. IOCV and FAO, Rome, Italy.

Roistacher, C. N., Bar-Joseph, M., and Gumpf, D. J. 1984. Transmission of tristeza and seedling yellows tristeza by small populations of Aphis gossypii. Plant Dis. 68:494-496.

Ruiz-Ruiz, S., Moreno, P., Guerri, J., and Ambrós, S. 2009. Discrimination between mild and severe Citrus tristeza virus isolates with a rapid and highly specific real-time reverse transcription-polymerase chain reaction method using TaqMan LNA probes. Phytopathology 99:307-315.

Selvaraj, V., Maheshwari, Y., Hajeri, S., and Yokomi, R. 2019. A rapid detection tool for VT isolates of Citrus tristeza virus by immunocapture-reverse transcriptase loop-mediated isothermal amplification assay. PLoS One 14: e0222170.

Sisterson, M. S., Ledbetter, C. A., Chen, J., Higbee, B. S., Groves, R. L., and Daane, K. M. 2012. Management of almond leaf scorch disease: Longterm data on yield, tree vitality, and disease progress. Plant Dis. 96: 1037-1044.

Sisterson, M. S., and Stenger, D. C. 2013. Roguing with replacement in perennial crops: Conditions for successful disease management. Phytopathology 103 117-128.

Vidalakis, G., da Graça, J. V., Dixon, W. N., Ferrin, D., Kesinger, M., Krueger, R. R., Lee, R. F., Melzer, M. J., Olive, J., Polek, M., Sieburth, P. J., Williams, L., and Wright, G. C. 2010. Citrus quarantine, sanitary, and certification programs in the USA: Prevention of introduction and distribution of citrus 
diseases. Part 2. Certification schemes and national programs. Highlights of new California citrus nursery regulations. Citrograph 1:27-39. http://www. citrusresearch.org/wp-content/uploads/CitrographJuly-August.pdf\#page=27

Yokomi, R., Selvaraj, V., Maheshwari, Y., Chiumenti, M., Saponari, M., Giampetruzzi, A., Weng, Z., Xiong, Z., and Hajeri, S. 2018. Molecular and biological characterization of a novel mild strain of citrus tristeza virus in California. Arch. Virol. 163:1795-1804.

Yokomi, R. K. 2019. CTV vectors and interactions with the virus and host plants. Pages 29-53 in: Citrus tristeza virus: Methods and Protocols. A. Catara, M Bar-Joseph, and G. Licciardello, eds. Humana Press, New York, NY, U.S.A.

Yokomi, R. K., and DeBorde, R. L. 2005. Incidence, transmissibility and genotype analysis of Citrus tristeza virus (CTV) from CTV eradicative and noneradicative districts in central California. Plant Dis. 89:859-866.
Yokomi, R. K., Lastra, R., Stoetzel, M. B., Damsteegt, V. D., Lee, R. F., Garnsey, S. M., Gottwald, T. R., Rocha-Peña, M. A., and Niblett, C. L. 1994 Establishment of the brown citrus aphid (Homoptera: Aphididae) in Central America and the Caribbean Basin and transmission of Citrus tristeza virus. J. Econ. Entomol. 87:1078-1085.

Yokomi, R. K., Saponari, M., and Sieburth, P. J. 2010. Rapid differentiation and identification of potential severe strains of Citrus tristeza virus by real-time reverse transcription-polymerase chain reaction assays. Phytopathology 100: 319-327.

Yokomi, R. K, Selvaraj, V., Maheshwari, Y., Saponari, M., Giampetruzzi, A., Chiumenti, M., and Hajeri, S. 2017. Identification and characterization of Citrus tristeza virus isolates breaking resistance in trifoliate orange in California. Phytopathology 107:901-908. 